\title{
Historical carbon fluxes in the expanding deforestation frontier of Southern Brazilian Amazonia (1985-2012)
}

\author{
Letícia de Barros Viana Hissa ${ }^{1}$ (1) Hannes Müller ${ }^{1}$ Ana Paula Dutra Aguiar $^{2}$ • \\ Patrick Hostert $^{1,3}$ - Tobia Lakes ${ }^{1,3}$
}

Received: 5 January 2016/Accepted: 2 November 2016/Published online: 24 November 2016

(c) The Author(s) 2016. This article is published with open access at Springerlink.com

\begin{abstract}
In tropical areas, pioneer occupation fronts steer the rapid expansion of deforestation, contributing to carbon emissions. Up-to-date carbon emission estimates covering the long-term development of such frontiers depend on the availability of high spatial-temporal resolution data. In this paper, we provide a detailed assessment of carbon losses from deforestation and potential forest degradation from fragmentation for one expanding frontier in the Brazilian Amazon. We focused on one of the Amazonia's hot-spots of forest loss, the BR-163 highway that connects the high productivity agricultural landscapes in Mato Grosso with the exporting harbors of the Amazon. We used multidecadal (1984-2012) Landsat-based time series on forested and non-forested area in combination with a carbon bookkeeping model. We show a $36 \%$ reduction in 1984 s biomass carbon stocks, which led to the emission of 611.5 $\mathrm{TgCO}_{2}$ between 1985 and $1998\left(43.6 \mathrm{TgCO}_{2}\right.$ year $^{-1}$ ) and $959.8 \mathrm{TgCO}_{2}$ over 1999-2012 (68.5 $\mathrm{TgCO}_{2}$ year $\left.^{-1}\right)$. Overall, fragmentation-related carbon losses represented $1.88 \%$ of total emissions by 2012 , with an increasing
\end{abstract}

Electronic supplementary material The online version of this article (doi:10.1007/s10113-016-1076-2) contains supplementary material, which is available to authorized users.

Letícia de Barros Viana Hissa

leticia.hissa@geo.hu-berlin.de

1 Department of Geography, Humboldt-Universität zu Berlin, Unter den Linden 6, 10099 Berlin, Germany

2 Earth System Science Center (CCST), National Institute for Space Research (INPE), Ministry of Science, Technology and Innovation (MCTI), Av. dos Astronautas 1758, São José dos Campos, SP CEP 12227-010, Brazil

3 Integrative Research Institute on Transformations of HumanEnvironment Systems, Humboldt Universität zu Berlin, Unter den Linden 6, 10099 Berlin, Germany relevance since 2004. We compared the Brazilian Space Agency deforestation assessment (PRODES) with our data and found that small deforestation polygons not captured by PRODES had increasing importance on estimated deforestation carbon losses since 2000. The comparative analysis improved the understanding of data-source-related uncertainties on carbon estimates and indicated disagreement areas between datasets that could be subject of future research. Furthermore, spatially explicit, annual deforestation and emission estimates like the ones derived from this study are important for setting regional baselines for REDD+ or similar payment for ecosystem services frameworks.

Keywords Carbon book-keeping - Deforestation - Forest degradation - Edge effects - Dataset uncertainty - INPEEM $\cdot$ Landsat

\section{Introduction}

Conserving Amazonia's massive forest carbon stocks is a central objective of the climate change mitigation debate. Even more, recent assessments point that it is important to recover large tracts of forest in the Amazon to promote carbon sequestration and restore the hydric regional balance (Nobre 2014). However, since the early 1960's, the Brazilian Amazon has lost $20 \%$ of pristine forest, over $760,000 \mathrm{~km}^{2}$ to clear-cutting deforestation alone (INPE 2014). As a consequence, deforestation in the Brazilian Amazon was a net source of $0.10-0.15 \mathrm{Pg} \mathrm{C}_{\text {year }}{ }^{-1}$ during the 2000's (Aguiar et al. 2012), accounting for $12 \%$ of the global land use and cover change (LUCC) emissions, and $1.5 \%$ of overall global $\mathrm{CO}_{2}$ emissions in 2009 (Le Quéré et al. 2009; Malhi 2010; Pan et al. 2011). Worthy to 
mention, Brazil's last decade's efforts to halt deforestation in the Amazon already pushed down emission rates, despite the fact that the agricultural frontier is moving toward higher-biomass density areas (Ometto et al. 2014). Still, we are far from affirming that deforestation will soon come to an end (Fearnside 2015) and even further away from a scenario of large-scale afforestation (Aguiar et al. 2016).

Despite its importance LUCC is the most uncertain component of the global carbon budget (Houghton et al. 2012). Different approaches have been proposed to deliver estimates, i.e., book-keeping models, dynamic vegetation models and earth system models (Pongratz et al. 2014). Carbon book-keeping models have been used in the past to quantify the effects of land use change on carbon stocks (Achard et al. 2004; DeFries et al. 2002; Houghton et al. 2000). They rely on the availability of datasets describing land use and cover trajectories to allocate carbon losses and gains temporally (Ramankutty et al. 2007), of information on biomass density and of knowledge to characterize carbon decay under different land management systems (Aguiar et al. 2012). Global or biome level studies depend on large datasets, often with moderate spatial resolution (Song et al. 2015) or temporal extent (Hansen et al. 2013) and aggregated census data (Imbach et al. 2015; Leite et al. 2012). Regional-scale assessments, on the other hand, can overcome methodological constraints, bringing insights to specific processes relevant to the carbon budget (Carlson et al. 2012; Toomey et al. 2013). On this matter, efforts to produce spatial-temporal information and modeling tools able to accurately represent and quantify emissions are critical (Asner et al. 2010). Newly available Landsatderived datasets covering deforestation since the early 1980's (Müller et al. 2016) provide the detail necessary to characterize long-term land use change and spatially heterogeneous carbon decay processes, such as emissions from biomass mortality due to edge effects and forest fragmentation (Numata et al. 2010). This is fundamental for understanding the long-term development of deforestation frontiers and the contribution of forest degradation to emerging emission patterns.

Pervasive land uses cause different levels of forest loss, with clear-cut deforestation being the most extreme. Forest fires and selective logging degradation also create gradients of forest loss and often develop positive feedbacks that intensify disturbances and carbon stocks depletion (Aragão et al. 2014). Although forest degradation affects only a percentage of forest carbon stocks, this process spanned an area almost two times the clear-cut extension across the Brazilian Amazon between 2007 and 2013 (INPE 2013) and could represent up to $47 \%$ of deforestation gross emissions (Aguiar et al. 2016). Another driver of forest degradation often neglected in carbon assessments is forest fragmentation leading to edge effects (Broadbent et al.
2008) which also interact with other degradation processes (e.g., understory fires). Increased exposure to adverse conditions (e.g., wind turbulence, light exposure, increased dryness) cause tree mortality and canopy gaps formation, potentially altering forest structure at edges, leading to aboveground biomass collapse (Berenguer et al. 2014; de Paula et al. 2011; Laurance et al. 1997; Nascimento and Laurance 2004).

In this study, we attempt to understand and quantify the impact of emerging spatial-temporal deforestation and edge emission patterns over almost 30 years along a deforestation frontier area, the influence area of the BR-163 highway, in southeastern Amazonia. Focusing on this area, we estimate historical carbon emissions from clear-cut deforestation and edge biomass collapse using the bookkeeping modeling framework INPE-EM (Aguiar et al. 2012), here augmented to assess emissions from forest fragmentation (Numata et al. 2010, 2011). We used annual deforestation maps between 1984 and 2012 with 30-m spatial resolution (Müller et al. 2016) as input, to derive spatial and temporal dynamics of forest edges. Specifically, the objectives of this study were to: (1) quantify potential carbon emissions from deforestation and edge creation for the period of 1985-2012; (2) uncover trends and spatialtemporal variability of biomass losses and carbon emissions and (3) quantify the impact of using different deforestation assessments (e.g., Müller et al. (2016) and the Brazilian Institute for Space Research deforestation assessment (PRODES) (INPE 2014)) on estimated carbon emissions.

\section{Material and method}

\section{Study area}

Our study area (Fig. 1a) extends $50 \mathrm{~km}$ around the BR-163 highway, following the road for $700 \mathrm{~km}$ from the city of Sinop in Mato Grosso (south) beyond Novo Progresso in Pará (north). It covers an area of $81,648 \mathrm{~km}^{2}$ from $5^{\circ} 30^{\prime}$ to $12^{\circ} 54^{\prime}$ southern latitude and $54^{\circ} 23^{\prime}$ to $56^{\circ} 18^{\prime}$ western longitude. The south-north natural vegetation gradient ranges from seasonal forests, over transitional evergreenseasonal forests to open and dense evergreen forests (RADAMBRASIL 1975). Climate ranges from tropical wet and dry in the south ( $A w$ in the Köppen Climate Classification) to tropical humid in the north ( $A m$ in the Köppen Climate Classification). Annual average temperatures range from 25.8 to $24.5{ }^{\circ} \mathrm{C}$ and total annual precipitation from 1800 to $2300(\mathrm{~mm})$ in Sinop and Novo Progresso, respectively (AmbiWeb 2015). The dry season extends from June to September. The influence are of the BR-163 is in average drier than other areas in the Amazon Biome, 

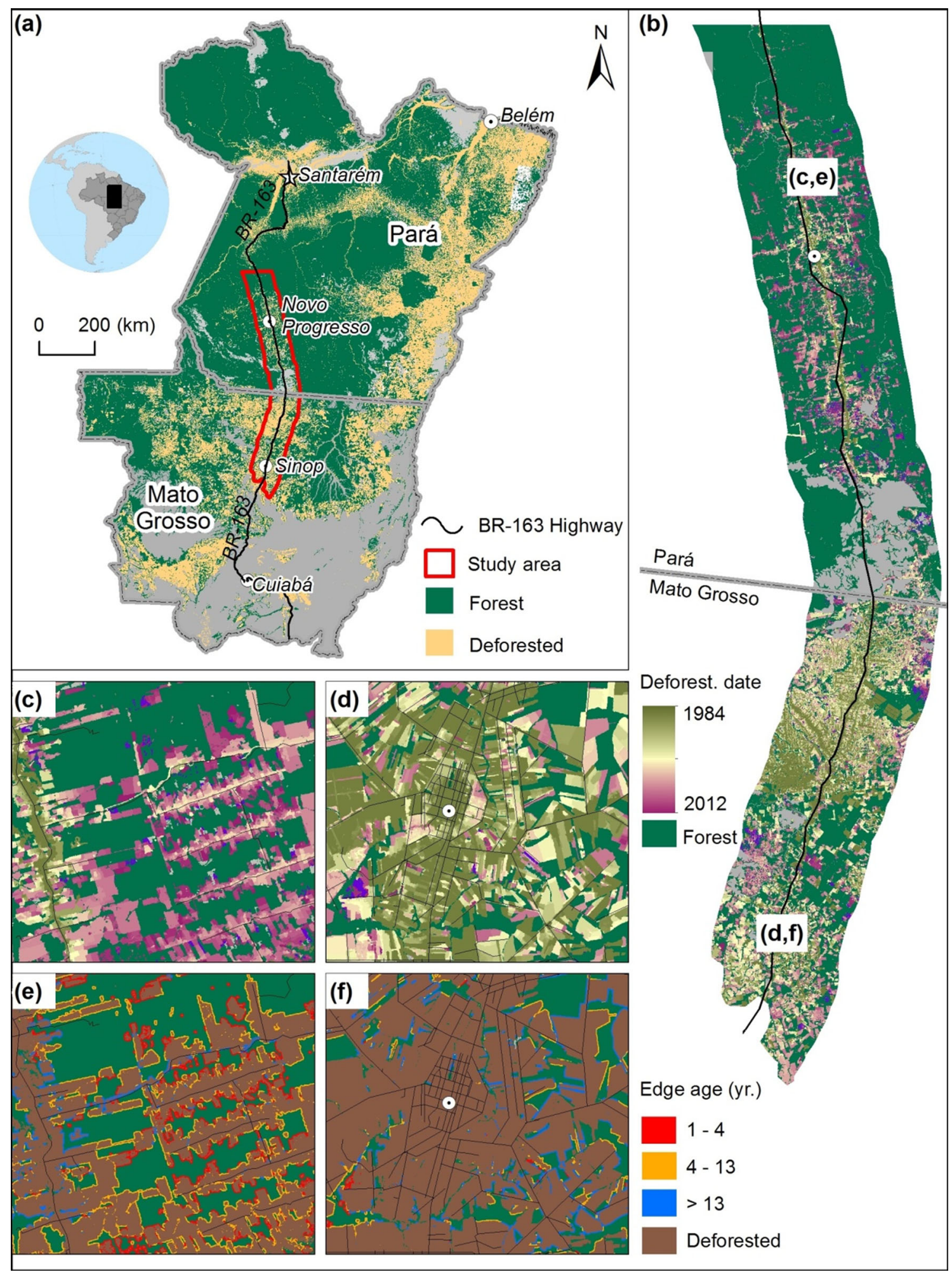

Fig. 1 a Location of the study area (in red) in relation to the federal states of Pará and Mato Grosso. b Annual deforestation in the study area (1984-2012). Different patterns of deforestation around Novo Progresso/PA (c) and Sinop/MT (d). Temporal structure of detected edges for a recently deforested area around Novo Progresso/PA (e) and older deforested area around Sinop/MT (f). Sources PRODES (INPE 2014; Müller et al. 2016) (color figure online) 
which facilitates agricultural activities in comparison with the surroundings (e.g., Santarém) (Fearnside 2007). On the other hand, the drier climate combined with increasing fragmentation and forest degradation also might increase the region's susceptibility to forest fires.

The BR-163 highway is an important transportation corridor connecting the soybean-producing areas in central Brazil with the regional and international market places through the harbors of Santarém and Itaituba (Fig. 1a). Deforestation began (Fig. 1b-d) following a spontaneous colonization process triggered by the construction of the section connecting Cuiabá (Mato Grosso) to Santarém (Pará) in the early seventies (Coy and Klingler 2014).

Even though the Brazilian government intensified monitoring operations and implemented measures to halt deforestation and illegal timber extraction along the BR163 (Fearnside 2007) and deforestation indeed has slowed down since 2004, the corridor is still a hot-spot of forest loss (INPE 2014). Today, the southern part of our study area, located in Mato Grosso, represents a stabilized agricultural landscape, dedicated to the production of soybeans, corn, cotton, as well as to cattle ranching. The northern part in the state of Pará is an agricultural expansion frontier, and the main economic activity is cattle ranching. With the road's pavement in its final stage in the state of Pará, the BR-163 highway is likely to even become the main route for agricultural commodities transportation from the entire Mato Grosso state (Correa and Ramos 2010). The BR-163 paving will likely foster economic development by promoting the integration of regional markets, which in an insufficient environmental law enforcement scenario could further encourage the advance of the deforestation frontier toward the inner Amazon (Fearnside 2007).

\section{Datasets on deforestation, forest edges and biomass}

We used old growth tropical forest cover and annual deforestation maps created by Müller et al. (2016) covering the time period between 1984 and 2012 (Fig. 1b-d). The authors used image compositing for 2224 Landsat TM and ETM+ images across 11 footprints (Griffiths et al. 2013). They mapped stable forest in 1984 and identified subsequent deforestation events using a random forest classifier with an overall accuracy of $85 \%$ (Müller et al. 2016). This dataset identifies deforestation on a per-pixel basis, i.e., at a 30-m spatial resolution, detecting clearing events as small as 0.1 ha. The authors state that small patches of savanna vegetation in hilly terrain were misclassified as deforestation areas during the classification process. We therefore filtered deforested patches equal or smaller than 1 ha to avoid overestimation of deforestation and edge effect emissions associated with savanna vegetation. This approach decreased the overall deforested area by $3.7 \%$. Based on a verification of 250 random samples, we estimate that $82 \%$ of removed pixels were indeed associated with savanna vegetation, while $18 \%$ were true deforestation events. Additional non-forest area (water bodies, savanna vegetation and rocks) and edges of forest fragments neighboring natural non-forest land cover were excluded from the analysis using PRODES data (see below). This preprocessing ensured a conservative measure of forest edge creation.

We defined forest cover associated with forest edges for each year using buffers along yearly created deforestation patches (Numata et al. 2009). We introduced a buffer of $120 \mathrm{~m}$ based on the findings of edge-related biomass mortality by Laurance et al. (1998). Since there is little consensus about the extent to which degradation affects forest at edges (Broadbent et al. 2008; Chaplin-Kramer et al. 2015; de Paula et al. 2016), we tested an additional edge width of $300 \mathrm{~m}$ (Numata et al. 2010; Shapiro et al. 2016). Edges that already existed at the starting year of our time series in 1984 were excluded from the analysis, as their age was unknown. From the resulting forest edge maps, we derived annual edge age information (Fig. 1e, f) to account for biomass losses and carbon emissions from edge permanence.

To compare the benefits of long-term high spatial resolution data with PRODES (as a baseline that has been frequently used and is often referred to), we ran our analysis using PRODES as input. The PRODES assessment delivers annual spatially explicit information on deforestation for the Brazilian Amazon since the year 2000, with a declared minimum mapping unit of 6.25 ha. Therefore, cleared areas below this threshold are not necessarily detected. Recent literature has pointed that the importance of small clearings to total deforestation (6.25-50 ha) increased since 2002 (Rosa et al. 2012) with potential implications for LUCC carbon accounting. It is expected that deforested areas smaller than 6.25 ha have also proportionally increased. However, until now, there were no datasets available to evaluate the importance of clearings smaller than 6.25 ha for deforestation and fragmentation carbon emissions. For this purpose, we compared both datasets to quantify emissions from deforestation and forest fragmentation since the year 2000.

To account for historical emissions, knowledge of original biomass is necessary. We therefore used a compilation of biomass content per vegetation type (IBGE 2004) based on Nogueira et al. (2008) and Leite et al. (2012). Nogueira et al. (2008) created a biomass map for the Brazilian Amazon combining inventory data, and soilcalibrated allometric equations applied to a forest type's map. Leite et al. (2012) compiled information for vegetation types not considered by Nogueira et al. (2008). The 
study area has a decreasing north-south biomass gradient, consistent with the Amazon-Cerrado-tropical forest to Brazilian Savanna transition. Biomass ranged between 8 and $320 \mathrm{t} / \mathrm{ha}$. We used aboveground biomass as a proxy for landscape carbon stocks to estimate above and belowground carbon losses. We used a below/aboveground biomass ratio of 0.3 to compute the belowground root biomass pool (BGB) (Aguiar et al. 2012).

\section{Modeling of carbon emissions}

Our work is based on INPE-EM, a carbon book-keeping model proposed by Aguiar et al. (2012), similar to earlier frameworks (Houghton et al. 2000; Ramankutty et al. 2007). INPE-EM calculates both immediate and gradual greenhouse gases emissions on annual steps based on several parameters calibrated specifically to reflect forest removal techniques used in the Amazon. While INPE-EM models both fluxes from carbon sources (i.e., from primary and secondary forests removal) and sinks (i.e., sequestration from secondary vegetation regrowth), for this study, we do not estimate the emissions balance. Instead, we calculate gradual carbon losses from deforestation and augmented INPE-EM to estimate carbon release due to edge effects. The lack of spatially explicit data for regrowth dynamics for the timeframe here investigated hampered the possibility of estimating a carbon balance. Originally, INPE-EM runs on the TerraME modeling environment (Carneiro et al. 2013), for the whole Legal Amazon using grid cells of $5 \times 5 \mathrm{~km}$. For this study, we adapted INPE-EM to run on Dinamica-EGO (Soares-Filho et al. 2009) using the native Landsat data spatial resolution of $30 \times 30 \mathrm{~m}$. INPE-EM's original code is available for free download (inpe-em.ccst.inpe.br/).

Laurance et al. (1997, 1998) identified for a study conducted in Central Amazonia that $8.8 \%$ of the aboveground live biomass present in forest edges died during the first years after forest fragmentation and $1.8 \%$ was lost due to tree damage, totaling $10.6 \%$, and that posterior losses were negligible. For modeling purposes, as in Numata et al. (2010, 2011), we distributed this potential biomass collapse $(\mathrm{BC}=10.6 \%)$ linearly during the first 4 years following edge creation, assuming a linear rate of $2.65 \%$ year $^{-1}$ (Eq. 1). Subsequent to biomass collapse, carbon losses are booked linearly at a yearly rate of $10 \%$. We consider that carbon content $(\mathrm{C})$ represents $48 \%$ of the biomass and used a conversion factor $(\mathrm{CF})$ of 3.67 to convert $\mathrm{C}$ to $\mathrm{CO}_{2}$ (Aguiar et al. 2012). When edge deforestation occurs before the collapsed biomass carbon decay process completion, the remaining carbon of the edge pool is accounted as deforestation emission, to avoid double booking. We consider that this remaining carbon content will be released through burning (Eq. 2). Burned biomass emissions are divided into five greenhouse gases (GHG): carbon monoxide $(\mathrm{CO})$, carbon dioxide $\left(\mathrm{CO}_{2}\right)$, nitrous oxide $\left(\mathrm{N}_{2} \mathrm{O}\right)$, mono-nitrogen oxides $\left(\mathrm{NO}_{\mathrm{x}}\right)$ and methane $\left(\mathrm{CH}_{4}\right)$ (Aguiar et al. 2012). We do not account for edge biomass recovery, since degradation favors shorter-lived successional trees and lianas, which have low wood density and biomass (Nascimento and Laurance 2004). The biomass map was updated annually by the edge component, meaning each pixel loses a percentage of original biomass according to edge permanence. As outputs we have annual update biomass maps, which were used as input for the deforestation emissions module.

Edge Permanence (EPe)

$$
\begin{aligned}
& =\left(\text { Biomass } \times \mathrm{BC}\left(\text { Edge Age } 1-4_{\mathrm{yr}}\right)\right) \\
& \times 0.1_{\mathrm{yr}} \times C \times \mathrm{CF}
\end{aligned}
$$

Edge Burning $(\mathrm{EB})=($ Edge Pool $-\mathrm{EPe}) \times \mathrm{GhG} \mathrm{CF}$

Annual deforestation data was overlaid with the biomass maps to estimate the yearly carbon release by deforestation. First, we considered that $15 \%$ of the aboveground biomass will be removed as commercial wood products $\left(P_{\mathrm{Wood}}=0.15\right)$. The $85 \%$ remaining aboveground biomass carbon content was divided between instantaneous emission through biomass burning $\left(P_{\text {fire }}=0.42\right)$ and legacy emissions of two different carbon pools, i.e., slash $\left(P_{\text {Slash }}=0.41\right)$ and elemental carbon $\left(P_{\text {Elem } C}=0.02\right)$ (Aguiar et al. 2012). Emissions from biomass burning were divided into five greenhouse gases, as explained above. Carbon release from wood products, slash and elemental carbon pools was distributed along the subsequent years following the deforestation event with different exponential decay rates (Eq. 3). Due to the cyclic use of fire in agriculture, our model considers that the slash pool will re-burn (ReburnCycle) every 3 years, accelerating carbon release to the atmosphere (Eq. 3). Total emissions were calculated as the sum of carbon losses from edge effects and deforestation. We start the carbon accounting from the year 1985 since deforestation events detected in 1984 reflect deforestation that occurred in that year and in previous years.

$$
\begin{aligned}
\text { Deforestation }= & \left(\left(P_{\text {Wood }}\right) \times 0.1_{\mathrm{yr}}\right)+\left(\left(\left(P_{\text {Slash }}\right) \times 0.4_{\mathrm{yr}}\right)\right. \\
& \times \text { Reburn Cycle })+\left(\left(P_{\text {Elem } C}\right) \times 0.001_{\mathrm{yr}}\right) \\
& +\left(\mathrm{BGB} \times 0.7_{\mathrm{yr}}\right)
\end{aligned}
$$

We ran an additional model exploration using the dataset available from PRODES (INPE 2014) to assess the impact of using different deforestation data on estimated emissions between 2001 and 2012. As a means to compare estimated emissions between the two products, we 
conducted the same procedures to create edge-affected area and temporal structure with the data from PRODES. Table S1 details data sources and parameters values for the different modeling explorations ran for this study.

\section{Edge and fragmentation analysis}

We analyzed three edge metrics to understand how landscape structure influences biomass stock changes and emission patterns in time and space. The edge-affected area is a measure of the absolute area of forest patch edges exposed, potentially causing forest disturbance (Numata et al. 2009). Large areas exposed to edge effects cause carbon losses; however, this process is only significant when the edge is not deforested quickly, allowing for the dead biomass to rapidly emit its carbon content. This process can be explained using the edge permanence time metric, which shows the average edge permanence time before it is deforested. The edge age composition was also calculated to illustrate how edges age and related carbon emissions decrease, especially if the landscape structure stabilizes (Numata et al. 2009).

\section{Results}

\section{Deforestation and forest edge dynamics}

In 2012, old growth forest covered 45,357 $\mathrm{km}^{2}$, i.e., $31 \%$ less forest than in 1984. Between 1984 and 2012, $9188 \mathrm{~km}^{2}$ of forest were lost in Pará and $18,065 \mathrm{~km}^{2}$ in Mato Grosso, 22 and $61 \%$ of the forest cover in 1984, respectively $\left(27,253 \mathrm{~km}^{2}\right.$ overall). Yearly, deforestation averaged $973 \mathrm{~km}^{2}$ (1.7\% year), reaching a maximum cleared area of $2172 \mathrm{~km}^{2}$ in 2004. The PRODES dataset (2001-2012) identified more cleared areas than Müller et al. (2016) (Figure S1a-b) in the first years of the period and less after 2006.

Accounted forest edge totaled $584 \mathrm{~km}^{2}$ at the beginning of our monitoring period, $82 \%$ of which were located in
Mato Grosso. This area augmented to $5727 \mathrm{~km}^{2}$ in 2012, a tenfold increase. In Mato Grosso, edge area increased strongest until 1989, with the accumulated edge area stabilizing after 2000 (Figure S2). Pará experienced increasing edge-affected area throughout the entire investigated period. Despite the expansion of deforestation in Mato Grosso, edge-affected area stabilized due to the balance between edge deforestation and edge creation (Numata et al. 2010), while net edge area increased along the active deforestation frontiers in Pará.

Edge age composition also explains the temporal patterns of edge biomass mortality and emissions. Only young forest edges (1-4 years) show active biomass mortality and from 2006 to 2012. Young forest edges accounted for $44 \%$ of all forest edges in the state of Pará, but only for $18 \%$ in Mato Grosso. Similarly, 5-13-year-old edges, which are still emitting carbon, were more present in Pará than in Mato Grosso (89\% compared to 66\%) (Figure S3a-b). We found for Mato Grosso that on average, $64 \%$ of all edges remained 4 years after creation, completing the biomass collapse process, and $29 \%$ remained for 13 years after edge creation, completing the carbon emission process. On average, we identified less deforestation along edges in Pará, where $69 \%$ of edges remained 4 years after creation and 39\% remained 13 years after edge creation (Figure $\mathrm{S} 4 \mathrm{a}-\mathrm{b})$.

\section{Biomass and carbon losses from deforestation and edge effects}

By 2012, 36\% (974.3 Tg) of old growth forests' biomass C stocks were lost emitted, including belowground stocks. Of this total, $944.59 \mathrm{Tg}\left(33.74 \mathrm{Tg}_{\mathrm{year}}{ }^{-1}\right)$ of the biomass was lost via deforestation and $29.71 \mathrm{Tg}\left(1.1 \mathrm{Tg} \mathrm{year}^{-1}\right)$ due to forest fragmentation, representing $3.3 \%$ of the losses (i.e., deforestation and fragmentation related; Table 1).

A total of $1571.38 \mathrm{TgCO}_{2}$ was emitted between 1985 and 2012, from deforestation and edge biomass mortality, averaging $56.12 \mathrm{TgCO}_{2}$ year $^{-1}$ (Table 1). Carbon emissions increased until 2004, the year with the largest forest

Table 1 Biomass losses and emissions from deforestation and forest fragmentation (1984-2012)

\begin{tabular}{|c|c|c|c|c|c|c|c|c|}
\hline & $\begin{array}{l}\text { Old growth } \\
\text { forests } \\
\text { biomass stock }\end{array}$ & $\begin{array}{l}\text { Deforestation } \\
\text { biomass loss } \\
(\mathrm{Tg})\end{array}$ & $\begin{array}{l}\text { Edge } \\
\text { biomass } \\
\text { loss }(\mathrm{Tg})\end{array}$ & $\begin{array}{l}\text { Total } \\
\text { biomass } \\
\text { loss }(\mathrm{Tg})\end{array}$ & $\begin{array}{l}\text { Deforestation } \\
\text { emissions } \\
\left(\mathrm{TgCO}_{2}\right)\end{array}$ & $\begin{array}{l}\text { Edge biomass } \\
\text { mortality emissions } \\
\left(\mathrm{TgCO}_{2}\right)\end{array}$ & $\begin{array}{l}\text { Fragmentation } \\
\text { relevance }(\%)\end{array}$ & $\begin{array}{l}\text { Total } \\
\text { emissions } \\
\left(\mathrm{TgCO}_{2}\right)\end{array}$ \\
\hline Total & - & 944.59 & 29.71 & 974.30 & 1541.78 & 29.60 & 1.88 & 1571.38 \\
\hline 1985 & 2519.79 & 31.76 & - & 31.76 & 18.07 & - & - & 18.07 \\
\hline $\begin{array}{l}\text { Maximum } \\
\text { (2004) }\end{array}$ & 1801.92 & 76.48 & 1.38 & 77.86 & 101.82 & 1.3 & 1.26 & 103.13 \\
\hline 2012 & 1577.24 & 16.98 & 1.17 & 18.15 & 42.23 & 1.64 & 3.74 & 43.88 \\
\hline Average & - & 33.74 & 1.10 & 35.17 & 55.06 & 1.10 & 1.91 & 56.12 \\
\hline
\end{tabular}

Maximum, higher losses for the time series 

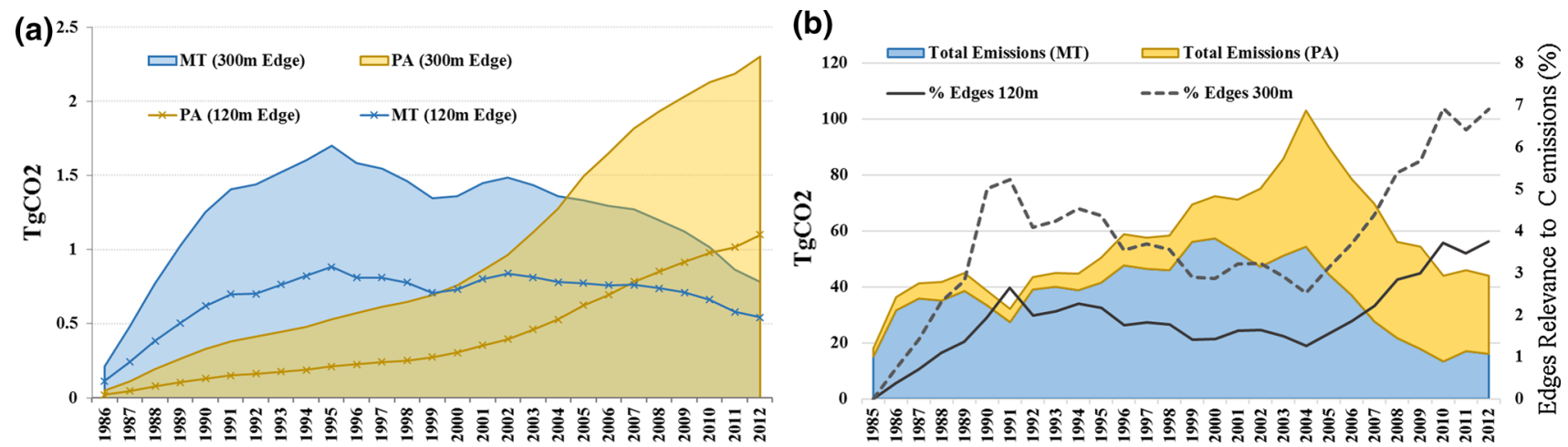

Fig. 2 Annual emissions from deforestation 1985-2012 (a) and forest fragmentation (b)

loss (Fig. 2a) peaking at $103.13 \mathrm{TgCO}_{2}$. Mato Grosso accounted for $65 \%$ of total emissions, releasing $1030.15 \mathrm{TgCO}_{2}$ by 2012, whereas Pará emitted the remaining $35 \%\left(541.22 \mathrm{TgCO}_{2}\right)$ (Fig. 2a). Important to notice, the area covering Mato Grosso represents $43 \%$ of our study area, which reinforces the importance of Mato Grosso on regional carbon losses. After 1999, a new deforestation frontier began to expand in Pará, concentrating this state's emissions in the second half of the investigated period (82\%), whereas losses in Mato Grosso were distributed more evenly across the entire monitored period. After 2004, deforestation was in line with the generally decreasing trend observed for the Brazilian Amazon, with a lagged effect on carbon emissions.

Edge carbon emissions increased over the entire period (1985-2012) (Fig. 2b). Edges emission trends were less sensible to biomass losses than deforestation emissions (Fig. 2a), since the edge carbon decay takes 13 years to be completed, whereas, in our model, the majority of deforestation carbon losses are related to fast emitting pools (e.g., fire, BGB). Forest edge biomass mortality led to the emission of $29.6 \mathrm{TgCO}_{2}$ between 1985 and $2012(0.36$ $\mathrm{TgC}$ year $^{-1}$ ), with Mato Grosso accounting for $61 \%$ of edge losses. Edge emissions play a small role in the overall carbon losses (Fig. 2a), averaging $1.88 \%$ during 1985-2012, and reached a maximum of $3.7 \%$ of the total emissions in 2010. The sensitivity analysis showed that considering a $300 \mathrm{~m}$ penetration of edge effects increases the emissions to $59.6 \mathrm{TgCO}_{2}$ (Fig. 2a) in our study area (i.e., an additional emission of $30 \mathrm{TgCO}_{2}$ from edges), leading also to an increased average relative importance of edge-related emissions of $3.7 \%$, peaking $6.9 \%$ in 2010, of overall carbon emissions. The reduced edge-area creation combined with edge aging in Mato Grosso determined a downward trajectory of carbon losses triggered by forest fragmentation (Fig. 2b) within the last 3 years of the time series. On the other hand, the pronounced increase in edgeaffected area (Figure S2) experienced in the 2000's boosted edge carbon losses in Pará (Fig. 2a).

\section{Deforestation, biomass losses and carbon emissions estimates using PRODES}

According to PRODES, deforested area totaled $24,455 \mathrm{~km}^{2}$ by 2012 , of which $11,171 \mathrm{~km}^{2}$ were cleared between 2001 and 2012, with an average rate of $931 \mathrm{~km}^{2}$ year ${ }^{-1}$. For the same period (2001-2012), Müller et al. (2016) detected a total deforestation of $12,559 \mathrm{~km}^{2}$ at a rate of $1046 \mathrm{~km}^{2}$. year $^{-1}$. Both datasets presented a marked decline of all clearing sizes contribution to total deforestation (Figure S1a-b). One exception was the class size smaller than 6.25 ha, only detected by Müller et al. (2016), which remained practically stable over time (Figure S1a). Using the PRODES data, we detected a total of $558 \mathrm{~km}^{2}$ of edges in 2001, increasing to $2953 \mathrm{~km}^{2}$ in 2012 . This is $23 \%$ less compared to the edge area estimates based on Müller et al. (2016) for the same period (501 and $3866 \mathrm{~km}^{2}$, respectively).

The comparison between the PRODES and Müller et al. (2016) datasets for the period between 2001 and 2012 revealed that biomass losses from deforestation and forest degradation were slightly smaller using the official PRODES product. Accumulated deforestation biomass losses totaled 415.32 $\mathrm{Tg}$ according to Müller et al. (2016) and $371.61 \mathrm{Tg}$ using the PRODES information (11\% of difference). Regarding edge biomass mortality, the disparity was smaller as for Müller et al. (2016), we estimated $12.58 \mathrm{Tg}$ losses, and using PRODES, we obtained 11.52 $\mathrm{Tg}, 8.8 \%$ less. Both datasets show similar patterns of deforestation, despite annual variation in rates, with decreasing numbers after 2004. However, the reduction detected by Müller et al. (2016) was not as strong as detected by PRODES, which led to higher estimates using the first dataset.

The simulations from 2001 to 2012 using PRODES deforestation information yielded $9.4 \%$ lower overall carbon losses compared to Müller et al. 2016 (635.2 $\mathrm{TgCO}_{2}$ and $701.5 \mathrm{TgCO}_{2}$ ). Since edge emissions have slower decay rates, the increased biomass losses detected using 
Müller et al. (2016) as reference data were not translated into higher emission rates by 2012 . Therefore, edge carbon losses estimated using the PRODES data as reference were $10.7 \%$ larger than using Müller et al. (2016).

\section{Discussion}

In this paper, we aimed for the quantification of carbon emissions from deforestation and forest degradation due to edge effects for the period between 1985 and 2012. Our findings showed that in 28 years, our study area lost a considerable amount of forest biomass (36\% of stocks present in 1984) and consequently of carbon to the atmosphere $\left(1571.38 \mathrm{TgCO}_{2}\right)$. Moreover, $57 \%$ of biomass losses from deforestation and $54 \%$ of biomass losses from forest fragmentation occurred before 2001-the year when spatially explicit information on deforestation became available from PRODES - indicating the importance of longterm analysis. On average, aboveground biomass density of deforested areas increased, due to the shift of forest loss from Mato Grosso to Pará, where higher-biomass forest types such as open and dense evergreen forests are more frequent. The increase in biomass density in deforested areas is in line with findings of other studies (Aguiar et al. 2012; Loarie et al. 2009; Ometto et al. 2014) and has implications for the overall magnitude of carbon losses.

Carbon losses along the BR-163 represented a significant share of overall deforestation-driven emissions at state and biome levels. Using a similar biomass map and PRODES information (Fearnside et al. 2009) estimated for the whole state of Mato Grosso that, between 2006 and 2007, forest clearing removed $66 \mathrm{Tg}$ year $^{-1}$ of biomass, including the belowground pool. This means that for the same period, the BR-influence area accounted for $42 \%$ of this total, while at the same time representing $<10 \%$ of the area. A comparison of our outputs with results from Aguiar et al. (2012) also show the increasing relevance of the BR163 corridor for the carbon losses in the Brazilian Amazon. Forest loss in the influence area of the BR-163 in relation to the Legal Amazon (BLA) increased from 6\% in 2001 to $10 \%$ in 2012, reaching $14 \%$ of the BLA's deforestation in 2011. This increase was accompanied by a rise in the weight of carbon losses in the BR-163 when compared to the BLA of 7.9-9.9\% for the same period. While it is yet unclear whether post-deforestation management practices can enhance carbon soil storage (Boy et al. 2016), we show that deforestation itself is a relevant source of carbon, and that land-related mitigation strategies should focus mainly on forest losses prevention. Still, adequate land management holds great importance by restraining demand for additional land, improving livelihoods, having a positive impact on aboveground carbon stocks conservation.
This is the first study to map historical multi-decadal carbon emissions from deforestation along the BR-163 frontier. Our results showed that biomass losses and carbon emission magnitude and trajectories were markedly influenced by deforestation dynamics and fragmentation patterns. Deforestation rates varied significantly over the past three decades and across space (Fig. 1a). Consistent with the frontier development along the BR-163, most of Mato Grosso's carbon losses occurred during the first 15 years of our analysis (1985-1999), while Pará presented higher losses from 2000 to 2012. By 2000, our study area in Mato Grosso was already a deforestation-saturated area, with most private properties presenting less forest area than the $80 \%$ legal reserve determined by the forest code (Stickler et al. 2013). In addition, between 1999 and 2001, the state government undertook a licensing and control program to stop deforestation (Fearnside and Barbosa 2004). As a consequence, the high opportunity costs of deforestation in Mato Grosso displaced the demand for land to southern Pará (Gollnow and Lakes 2014), increasing deforestation and carbon emissions after 2000. Short after, policy interventions (Börner et al. 2015; Soares-Filho et al. 2010) and voluntary market mechanisms (Gibbs et al. 2015) decreased deforestation rates and related carbon emissions in both states. However, while the Brazilian Amazon deforestation rates have dropped to $70 \%$ below the 1996-2005 average (the period that Brazil uses as the official baseline)_-bringing the country closer to the target of reaching the $80 \%$ reduction by 2020 - in our study area, the decrease was much lighter, of approximately $35 \%$ and only $18 \%$ in Pará. By shading light to the study area's historical trends, we were able to compare the region's baseline, which was unavailable before, to the Amazon's, making it clear that the BR-163 influence area is a source of LUCC carbon and a priority area for implementing law enforcement against illegal deforestation.

Next to Numata et al. $(2010,2011)$, this is one of the few studies that has quantified potential carbon losses related to edge effects for the Brazilian Amazon. Forest fragmentation represented a small share of biomass losses and carbon emissions throughout the investigated period, with an increasing importance after 2004 (Fig. 2a). Numata et al. (2011) identified the same pattern when analyzing edge contribution to total emissions in the Brazilian Amazon. The relative importance of fragmentation carbon losses enlarged with pioneer frontiers consolidation. Edge biomass mortality, unlike deforestation, led to a continuous rise in carbon losses during 1985-2012 (Fig. 2b), also contributing to a larger part of edge losses on total emissions. This was due to a number of factors. First, increasing forest losses expanded the edge-affected area (Figure S2), mainly in Pará, making more biomass vulnerable to disturbance and degradation. Thereafter, edge permanence 
time increased as deforestation rates dropped, making edges stable enough to complete the carbon decay process. The relative importance of edges to deforestation and fragmentation biomass losses in our study area is smaller than found by other studies, though. Numata et al. (2010) found that in the Brazilian state of Rondônia, edges accounted for $8.1 \%$ of combined biomass losses from forest clearing and edges, while we estimate a $2.95 \%$ contribution for our study area. This disparity is likely due to different fragmentation levels and deforestation geometry in the two regions, a pattern also identified by Laurance et al. (1998). In Rondônia, landscape is more fragmented and fishbone deforestation patterns are predominant, typical of the many rural settlements in the state, creating more edge-affected area. Despite ongoing deforestation and fragmentation, our study area was still covered by large patches of forest and cleared areas followed a geometric deforestation pattern that is typical for mediumto large-size farms and leads to fewer edges and less biomass losses from edge effects. While deforestation reduction has been the target of many governmental policies, forest fragmentation has been a less prioritized issue in the Amazon. For instance, forest recovery requirements under the umbrella of the Brazilian Law, combined with the creation of protected areas, could consider landscape configuration in order to reduce carbon emissions from forest edge degradation.

The edge emissions model implemented was based on the work of Numata et al. (2010, 2011). However, although the framework was effective to assess fragmentation-related carbon losses using extended time series of deforestation data, there are limitations to be addressed. Chief among those is the assumption that biomass mortality occurs at an identical rate in edges, at a fixed spatial range across the study area. Both parameters (mortality rate and edge width) are variable at local scale depending on different environmental and ecological factors such as forest edge adjacencies to different land use types, extreme climatic events (e.g., droughts) and forest fires. A study conducted in Central Amazonia by Mesquita et al. (1999) found, for example, that edges surrounded by pastures showed 55-100\% higher tree mortality rates than edges surrounded by secondary forests. Edge effects also propagated further into inner forests surrounded by pastures (60-100 m) in comparison with forests surrounded by regrowing vegetation $(0-60 \mathrm{~m})$ (Mesquita et al. 1999). Episodic droughts also contribute to edge effects' variability. For instance, Laurance et al. (2001) investigated possible edge effects associated with droughts caused by the El Nino-Southern Oscillation (ENSO) and found a significant increase in tree mortality rates during the ENSO drought, for a study area in Central Amazonia. Finally, fire occurrence could be relevant since most understory fires occur at up to $1 \mathrm{~km}$ of forest edges (Berenguer et al. 2014). Future research should focus on a more detailed and dynamic representation of the heterogeneous nature of edge effects in modeling carbon fluxes, including the above-mentioned processes.

In this study, we undertook a sensitivity analysis to account for different ranges of edge effects and a potential underestimation of potential carbon emissions. Other studies have also pointed out that edge-effects penetration affects forests at a range larger than $120 \mathrm{~m}$, indicating that our study could have underestimated potential carbon emissions. Chaplin-Kramer et al. (2015) suggested that edge effects could penetrate up to $5 \mathrm{~km}$ inside forests. However, this figure might be an overestimation due to the coarser spatial resolution data $(500 \mathrm{~m})$ used in the analysis (Pelletier et al. 2013; Chaplin-Kramer et al. 2015). Here, we test the effects of an edge width of $300 \mathrm{~m}$, which is in accordance with findings from recent studies (Shapiro et al. 2016) based on higher resolution remote sensing data. As expected, we found an increase in the relative importance of edges in relation to overall emissions, but lower than simulated by other studies (Pütz et al. 2014; ChaplinKramer et al. 2015).

By comparing two datasets, we could access datasources-related uncertainty in carbon estimation. Both deforestation assessments used in this study identified periods of increase (2001-2004) and decrease (2005-2012) of forest loss, with impacting consequences for estimated carbon emissions. However, annual deforestation rates and annual carbon losses differed between the two datasets, with a variation larger than $20 \%$ for most years, even though both products are based on Landsat imagery. Small deforestation events not detected by PRODES $(<6.25$ ha) partially explain the differences between datasets, accounting for $10 \%$ of biomass losses estimated based on Müller et al. (2016). Small-scale deforestation not only relates to PRODES limitations but also renders forest edges more important. In this context, we caution an underestimation of carbon emissions provided by carbon estimates relying purely on PRODES data, especially for the period after 2004 (Rosa et al. 2012). Further causes for variation among datasets are related to underlying conceptual and methodological definitions. On the one hand, the PRODES assessment is based on visual interpretation using single date images chosen at the peak of the dry season, potentially leading to late detection depending on the acquisition date (Câmara et al. 2006). On the other hand, Müller et al. (2016) use a compositing approach, which integrates all available cloud-free observations acquired during the dry season of a given year to extract the minimum tasseled cap wetness observation per pixel. This approach optimizes vegetation cover decrease detection and increases the chances of correctly labeling the occurrence year of 
deforestation events. In addition, low-intensity deforestation processes are a widespread phenomenon in our study area (Pinheiro et al. 2016) where full canopy removal often takes 2-3 years to be completed. While low-intensity deforestation is not explicitly included in the PRODES methodology, it leads to earlier deforestation detection in the approach by Müller et al. (2016). These methodological differences lead to irregular mismatches between the products which are extremely difficult to track.

Uncertainties related to carbon accounting stem from data sources (i.e., deforestation and biomass datasets) and model parameterization. In this study, we did not estimate the impact of different aboveground biomass datasets on biomass and carbon losses quantification. However, it is important to stress that a number of studies (Baccini et al. 2012; Nogueira et al. 2008; Saatchi et al. 2007, 2011; Sales 2010) have provided aboveground biomass estimates for the Brazilian Amazon and tropical areas, showing considerable disagreement (Fearnside 2016; Mitchard et al. 2013). Recent spatially explicit biomass maps (Baccini et al. 2012; Saatchi et al. 2011) created from a combination of remote sensing products (optical and LIDAR) with field assessments represent a major step forward toward reliable biomass estimates. However, biomass estimates based on recently available remote sensing data have limited use for historic emission assessments.

\section{Conclusions}

In this study, we assessed the carbon implications of the expansion of a deforestation frontier in the Amazon. Our study profited from deforestation data dating back to the mid-1980s covering almost the entire development of the influence area of the BR-163 highway Cuiabá-Santarém. We conclude that this region followed the overall trends in deforestation and carbon emissions of the Amazon, but with a lesser decrease in forest losses, especially in Pará. This calls attention for policy makers about the need to direct more efforts to stop illegal deforestation in the region and the potential of REDD+ programs. Also, important to mention that, besides uncovering past biomass losses and carbon emissions trends, extended time series of annual deforestation are fundamental for establishing carbon losses reduction targets baselines for REDD+ programs in sub-national and regional levels.

The extended time series allowed us to investigate longterm potential carbon decay of fragmentation resulting forest edges and to confirm the increasing relevance of edge effects on carbon emissions in consolidating deforestation frontiers. Next to Numata et al. (2010), this is the only study which provides such estimates based on a multidecadal time deforestation series. However, it is important to stress that we offer an assessment of potential carbon losses, and that a thorough assessment of the geographical variation of edge effects intensity is a knowledge gap to be filled.

The high spatial resolution of the dataset allowed us to investigate the contribution of small deforestation polygons $(<6.25 \mathrm{ha})$ to carbon emissions, revealing a non-negligible contribution of small clearings to carbon losses. Furthermore, our approach improves carbon estimates reliability since it provides a quantification of uncertainty, caused by deforestation products. For that matter, we demonstrated that variations in deforestation products yielded average differences in carbon emissions of $11 \%$, and PRODESbased estimates likely underestimate carbon emissions since 2004.

Whether deforestation and related carbon emissions will continue to drop or increase is uncertain, especially in southwestern Pará, a region particularly vulnerable to speculative deforestation (Fearnside 2008; Margulis 2004). Recent reports by PRODES indicated spikes in deforestation rates in 2013 and 2015 after one decade of sharpen decrease, a red alert for policy makers that the current deforestation prevention model might be exhausted and that new approaches could be necessary. Therefore, the future of carbon stocks from the Amazon is highly uncertain, and more detailed studies, e.g., confronting monitoring products uncertainties and limitations and including a differentiated representation of edge effects and forest changes in modeling carbon fluxes, will be needed in the future to support decision making.

Acknowledgements Leticia Hissa acknowledges the financial support from CAPES/Science Without Borders program. BEX 104713-2. This work has been supported by the Brazilian-German cooperation project on "Carbon sequestration, biodiversity and social structures in Southern Amazonia (CarBioCial, see www.carbiocial.de)" and financed by the German Ministry of Research and Education (BMBF, Project No. 01LL0902). We are grateful to the editors and the two anonymous reviewers for their comments which helped to significantly improve an earlier version of the manuscript.

Open Access This article is distributed under the terms of the Creative Commons Attribution 4.0 International License (http://crea tivecommons.org/licenses/by/4.0/), which permits unrestricted use, distribution, and reproduction in any medium, provided you give appropriate credit to the original author(s) and the source, provide a link to the Creative Commons license, and indicate if changes were made.

\section{References}

Achard F, Eva HD, Mayaux P, Stibig H-J, Belward A (2004) Improved estimates of net carbon emissions from land cover change in the tropics for the 1990s. Global Biogeochem Cycles. doi: $10.1029 / 2003 \mathrm{gb} 002142$ 
Aguiar APD, Ometto JP, Nobre C, Lapola DM, Almeida C, Vieira IC, Soares JV, Alvala R, Saatchi S, Valeriano D, Castilla-Rubio JC (2012) Modeling the spatial and temporal heterogeneity of deforestation-driven carbon emissions: the INPE-EM framework applied to the Brazilian Amazon. Glob Change Biol 18:3346-3366. doi:10.1111/j.1365-2486.2012.02782.x

Aguiar APD, Vieira IC, Assis TO, Dalla-Nora EL, Toledo PM, Santos-Junior RA, Batistella M, Coelho AS, Savaget EK, Aragão LE, Nobre CA, Ometto JP (2016) Land use change emission scenarios: anticipating a forest transition process in the Brazilian Amazon? Glob Change Biol 22(5):1821-1840. doi:10.1111/gcb. 13134

AmbiWeb (2015) Climate-data.org. http://de.climate-data.org/loca tion/33886/

Aragão LEOC, Poulter B, Barlow JB, Anderson LO, Malhi Y, Saatchi S, Phillips OL, Gloor E (2014) Environmental change and the carbon balance of Amazonian forests. Biol Rev Camb Philos Soc 89:913-931. doi:10.1111/brv.12088

Asner GP, Powell GVN, Mascaro J, Knapp DE, Clark JK, Jacobson J, Kennedy-Bowdoin T, Balaji A, Paez-Acosta G, Victoria E, Secada L, Valqui M, Hughes RF (2010) High-resolution forest carbon stocks and emissions in the Amazon. Proc Natl Acad Sci 107:16738-16742. doi:10.1073/pnas.1004875107

Baccini A, Goetz SJ, Walker WS, Laporte NT, Sun M, Sulla-Menashe D, Hackler J, Beck PSA, Dubayah R, Friedl MA, Samanta S, Houghton RA (2012) Estimated carbon dioxide emissions from tropical deforestation improved by carbon-density maps. Nat Clim Change 2:182-185. doi:10.1038/nclimate1354

Berenguer E, Ferreira J, Gardner TA, Aragão LEOC, De Camargo PB, Cerri CE, Durigan M, Oliveira RCD, Vieira ICG, Barlow J (2014) A large-scale field assessment of carbon stocks in humanmodified tropical forests. Glob Change Biol 20:3713-3726. doi: $10.1111 / \mathrm{gcb} .12627$

Börner J, Kis-Katos K, Hargrave J, König K (2015) Post-crackdown effectiveness of field-based forest law enforcement in the Brazilian Amazon. PLoS ONE 10:e0121544. doi:10.1371/ journal.pone. 0121544

Boy J, Strey S, Schönenberg R, Weber-Santos O, Nendel C, Strey R, Klingler M, Schumann C, Hartberger K, Guggenberger G (2016) Seeing the forest not for the carbon-why concentrating on landuse-induced carbon stock changes of soils can be climateunfriendly. Reg Environ Change. doi:10.1007/s10113-016-1008-1

Broadbent EN, Asner GP, Keller M, Knapp DE, Oliveira PJC, Silva JN (2008) Forest fragmentation and edge effects from deforestation and selective logging in the Brazilian Amazon. Biol Conserv 141:1745-1757. doi:10.1016/j.biocon.2008.04.024

Câmara G, Valeriano D, Soares JV (2006) Metodologia para o Cálculo da Taxa Anual de Desmatamento na Amazônia Legal. INPE, Sao Jose dos Campos

Carlson KM, Curran LM, Ratnasari D, Pittman AM, Soares-Filho BS, Asner GP, Trigg SN, Gaveau DA, Lawrence D, Rodrigues HO (2012) Committed carbon emissions, deforestation, and community land conversion from oil palm plantation expansion in West Kalimantan, Indonesia. Proc Natl Acad Sci 109:7559-7564. doi:10.1073/pnas.1200452109

Carneiro TGS, Andrade P, Câmara G, Monteiro AMV, Pereira RR (2013) An extensible toolbox for modeling nature-society interactions. Environ Model Softw 46:104-117. doi:10.1016/j. envsoft.2013.03.002

Chaplin-Kramer R, Ramler I, Sharp R, Haddad NM, Gerber JS, West PC, Mandle L, Engstrom P, Baccini A, Sim S, Müller C, King H (2015) Degradation in carbon stocks near tropical forest edges. Nat Commun. doi:10.1038/ncomms10158

Correa VHC, Ramos P (2010) A precariedade do transporte rodoviário Brasileiro para o escoamento da produção de soja do Centro-Oeste: situação e perspectivas. Revista de Economia e Sociologia Rural 48:25

Coy M, Klingler M (2014) Frentes pioneiras em transformação: O eixo da BR-163 e os desafios socioambientais. Revista Territórios e Fronteiras 7:26

de Paula MD, Costa CA, Tabarelli M (2011) Carbon storage in a fragmented landscape of Atlantic forest: the role played by edgeaffected habitats and emergent trees. Trop Conserv Sci 4:10

de Paula MD, Groeneveld J, Huth A (2016) The extent of edge effects in fragmented landscapes: insights from satellite measurements of tree cover. Ecol Indic 69:196-204. doi:10.1016/j.ecolind. 2016.04.018

DeFries RS, Houghton RA, Hansen MC, Field CB, Skole D, Townshend J (2002) Carbon emissions from tropical deforestation and regrowth based on satellite observations for the 1980s and 1990s. Proc Natl Acad Sci 99:14256-14261. doi:10.1073/ pnas. 182560099

Fearnside PM (2007) Brazil's Cuiaba-Santarem (BR-163) highway: the environmental cost of paving a soybean corridor through the Amazon. Environ Manag 39:601-614. doi:10.1007/s00267-0060149-2

Fearnside PM (2008) The roles and movements of actors in the deforestation of Brazilian Amazonia. Ecol Soc 13(1):23

Fearnside PM (2015) Environment: deforestation soars in the Amazon. Nature 521:1. doi:10.1038/521423b

Fearnside PM (2016) Brazil's Amazonian forest carbon: the key to Southern Amazonia's significance for global climate. Reg Environ Change. doi:10.1007/s10113-016-1007-2

Fearnside PM, Barbosa RI (2004) Accelerating deforestation in Brazilian Amazonia: towards answering open questions. Environ Conserv 31:7-10. doi:10.1017/s0376892904001055

Fearnside PM, Righi CA, Graça P, Keizer EWH, Cerri CC, Nogueira EM, Barbosa RI (2009) Biomass and greenhouse-gas emissions from land-use change in Brazil's Amazonian "arc of deforestation": the states of Mato Grosso and Rondônia. For Ecol Manag 258:1968-1978. doi:10.1016/j.foreco.2009.07.042

Gibbs HK, Rausch L, Munger J, Schelly I, Morton DC, Noojipady P, Soares-Filho BS, Barreto P, Micol L, Walker NF (2015) Brazil's soy moratorium. Science 347:377-378. doi:10.1126/science.aaa0181

Gollnow F, Lakes T (2014) Policy change, land use, and agriculture: the case of soy production and cattle ranching in Brazil, 2001-2012. Appl Geogr 55:203-211. doi:10.1016/j.apgeog. 2014.09.003

Griffiths P, van der Linden S, Kuemmerle T, Hostert P (2013) A pixel-based landsat compositing algorithm for large area land cover mapping. IEEE J Sel Top Appl Earth Obs Remote Sens 6:2088-2101. doi:10.1109/jstars.2012.2228167

Hansen MC, Potapov PV, Moore R, Hancher M, Turubanova SA, Tyukavina A, Thau D, Stehman SV, Goetz SJ, Loveland TR, Kommareddy A, Egorov A, Chini L, Justice CO, Townshend JRG (2013) High-resolution global maps of 21st-century forest cover change. Science 342:850-853. doi:10.1126/science. 1244693

Houghton RA, Skole DL, Nobre CA, Hackler JL, Lawrence KT, Chomentowski WH (2000) Annual fluxes of carbon from deforestation and regrowth in the Brazilian Amazon. Nature 403:301-304. doi:10.1038/35002062

Houghton RA, House JI, Pongratz J, van der Werf GR, DeFries RS, Hansen MC, Le Quéré C, Ramankutty N (2012) Carbon emissions from land use and land-cover change. Biogeosciences 9:5125-5142. doi:10.5194/bg-9-5125-2012

IBGE (2004) Mapa de Vegetação Original do Brasil. Instituto Brasileiro de Geografia e Estatística, Rio de Janeiro

Imbach P, Manrow M, Barona E, Barretto A, Hyman G, Ciais P (2015) Spatial and temporal contrasts in the distribution of crops 
and pastures across Amazonia: a new agricultural land use data set from census data since 1950. Global Biogeochem Cycles 29(6):898-916. doi:10.1002/2014gb004999

INPE (2013) DEGRAD—Programa de monitoramento de degradação florestal na Amazônia Brasileira. http://www.obt.inpe.br/degrad/

INPE (2014) PRODES: Programa de monitoramento do desmatamento na Amazônia Brasileira. http://www.obt.inpe.br/prodes/ index.php

Laurance WF, Laurance SG, Ferreira LV, Rankin-de Merona JM, Gascon C, Lovejoy TE (1997) Biomass collapse in amazonian forest fragments. Science 278:1117-1118. doi:10.1126/science. 278.5340 .1117

Laurance WF, Laurance SG, Delamônica P (1998) Tropical forest fragmentation and greenhouse gas emissions. For Ecol Manag 110:173-180. doi:10.1016/S0378-1127(98)00291-6

Laurance WF, Williamson GB, Delamônica P, Oliveira A, Lovejoy TE, Gascon C, Pohl L (2001) Effects of a strong drought on Amazonian forest fragments and edges. J Trop Ecol 17:771-785. doi:10.1017/S0266467401001596

Le Quéré C, Raupach MR, Canadell JG, Marland G, Bopp L, Ciais P, Conway TJ, Doney SC, Feely RA, Foster P, Friedlingstein P, Gurney K, Houghton RA, House JI, Huntingford C, Levy PE, Lomas MR, Majkut J, Metzl N, Ometto JP, Peters GP, Prentice IC, Randerson T, Running SW, Sarmiento JL, Schuster U, Sitch S, Takahashi T, Viovy N, van der Wer GR, Woodward FI (2009) Trends in the sources and sinks of carbon dioxide. Nat Geosci 2:831-836. doi:10.1038/ngeo689

Leite CC, Costa MH, Soares-Filho BS, de Barros Viana Hissa L (2012) Historical land use change and associated carbon emissions in Brazil from 1940 to 1995. Global Biogeochem Cycles. doi:10.1029/2011gb004133

Loarie SR, Asner GP, Field CB (2009) Boosted carbon emissions from Amazon deforestation. Geophys Res Lett. doi:10.1029/ $2009 \mathrm{~g} 1037526$

Malhi Y (2010) The carbon balance of tropical forest regions, 1990-2005. Curr Opin Environ Sustain 2:237-244. doi:10.1016/ j.cosust.2010.08.002

Margulis S (2004) Causes of deforestation of the Brazilian Amazon. World Bank, Washington, DC

Mesquita RCG, Delamônica P, Laurance WF (1999) Effects of surrounding vegetation on edge-related tree mortality in Amazonian forest fragments. Biol Conserv 91:129-134. doi:10.1016/ S0006-3207(99)00086-5

Mitchard E, Saatchi S, Baccini A, Asner G, Goetz S, Harris N, Brown $S$ (2013) Uncertainty in the spatial distribution of tropical forest biomass: a comparison of pan-tropical maps. Carbon Balance Manag 8:10. doi:10.1186/1750-0680-8-10

Müller H, Griffths P, Hostert P (2016) Long-term deforestation dynamics in the Brazilian Amazon-uncovering historic frontier development along the Cuiabá-Santarém highway. Int J Appl Earth Obs Geoinf 44:61-69. doi:10.1016/j.jag.2015.07.005

Nascimento HEM, Laurance WF (2004) Biomass dynamics in Amazonian forest fragments. Ecol Appl 14:127-138. doi:10. 1890/01-6003

Nobre AD (2014) O futuro climático da Amazônia vol 1, ARA/INPE/ INPA edn. ARA (Articulación Regional Amazônica). São Jose dos Campos

Nogueira EM, Fearnside PM, Nelson BW, Barbosa RI, Keizer EWH (2008) Estimates of forest biomass in the Brazilian Amazon: new allometric equations and adjustments to biomass from wood-volume inventories. For Ecol Manag 256:1853-1867. doi:10.1016/j.foreco.2008.07.022

Numata I, Cochrane MA, Roberts DA, Soares JV (2009) Determining dynamics of spatial and temporal structures of forest edges in South Western Amazonia. For Ecol Manag 258:2547-2555. doi:10.1016/j.foreco.2009.09.011
Numata I, Cochrane MA, Roberts DA, Soares JV, Souza CM, Sales MH (2010) Biomass collapse and carbon emissions from forest fragmentation in the Brazilian Amazon. J Geophys Res Biogeosci 115:G03027. doi:10.1029/2009JG001198

Numata I, Cochrane MA, Souza J, Carlos M, Sales MH (2011) Carbon emissions from deforestation and forest fragmentation in the Brazilian Amazon. Environ Res Lett 6:044003. doi:10.1088/ 1748-9326/6/4/044003

Ometto JP, Aguiar AP, Assis T, Soler L, Valle P, Tejada G, Lapola DM, Meir P (2014) Amazon forest biomass density maps: tackling the uncertainty in carbon emission estimates. Clim Change 124:545-560. doi:10.1007/s10584-014-1058-7

Pan Y, Birdsey RA, Fang J, Houghton RA, Kauppi PE, Kurz WA, Phillips OL, Shvidenko A, Lewis SL, Canadell JG, Ciais P, Jackson RB, Pacala SW, Mcguire DA, Piao S, Rautiainen A, Sitch A, Hayes D (2011) A large and persistent carbon sink in the world's forests. Science 333:988-993. doi:10.1126/science. 1201609

Pelletier J, Martin D, Potvin C (2013) REDD+ emissions estimation and reporting: dealing with uncertainty. Environ Res Lett 8:034009. doi:10.1088/1748-9326/8/3/034009

Pinheiro TF, Escada MIS, Valeriano DM, Hostert P, Gollnow F, Müller H (2016) Forest degradation associated with logging frontier expansion in the Amazon: the BR-163 region in Southwestern Pará, Brazil. Earth Interact. doi:10.1175/EI-D15-0016.1

Pongratz J, Reick CH, Houghton RA, House JI (2014) Terminology as a key uncertainty in net land use and land cover change carbon flux estimates. Earth Syst Dyn 5:177-195. doi:10.5194/esd-5$177-2014$

Pütz S, Groeneveld J, Henle K, Knogge C, Martensen AC, Metz M, Metzger JP, Ribeiro MC, de Paula MD, Huth A (2014) Longterm carbon loss in fragmented neotropical forests. Nat Commun. doi:10.1038/ncomms6037

RADAMBRASIL (1975) Projeto RADAMBRASIL-Vegetation Map

Ramankutty N, Gibbs HK, Achard F, Defries R, Foley JA, Houghton RA (2007) Challenges to estimating carbon emissions from tropical deforestation. Glob Change Biol 13:51-66. doi:10.1111/ j.1365-2486.2006.01272.x

Rosa IM, Souza C Jr, Ewers RM (2012) Changes in size of deforested patches in the Brazilian Amazon. Conserv Biol 26:932-937. doi:10.1111/j.1523-1739.2012.01901.x

Saatchi SS, Houghton RA, Dos Santos Alvalá RC, Soares JV, Yu Y (2007) Distribution of aboveground live biomass in the Amazon basin. Glob Change Biol 13:816-837. doi:10.1111/j.1365-2486. 2007.01323.x

Saatchi SS, Harris NL, Brown S, Lefsky M, Mitchard ETA, Salas W, Zutta BR, Buermann W, Lewis SL, Hagen S, Petrova S, White L, Silman M, Morel A (2011) Benchmark map of forest carbon stocks in tropical regions across three continents. Proc Natl Acad Sci 108:9899-9904. doi:10.1073/pnas.1019576108

Sales MH (2010) Estimating interpolation uncertainty of forest biomass stocks and carbon emissions from deforestation in the Brazilian Amazon using inventory data and geostatistics. University of California Santa Barbara, Santa Barbara

Shapiro AC, Aguilar-Amuchastegui N, Hostert P, Bastin JF (2016) Using fragmentation to assess degradation of forest edges in Democratic Republic of Congo. Carbon Balance Manag. doi:10. 1186/s13021-016-0054-9

Soares-Filho B, Rodrigues H, Costa W (2009) Modeling environmental dynamics with DINAMICA-EGO. CSR-UFMG, Belo Horizonte

Soares-Filho BS, Moutinho P, Nepstad D, Anderson A, Rodrigues H, Garcia R, Dietschi L, Merry F, Bowman M, Hissa L, Silvestrini R, Maretti C (2010) Role of Brazilian Amazon protected areas in 
climate change mitigation. Proc Natl Acad Sci 107:10821-10826. doi:10.1073/pnas.0913048107

Song XP, Huang C, Saatchi SS, Hansen MC, Townshend JR (2015)

Annual carbon emissions from deforestation in the Amazon Basin between 2000 and 2010. PLoS ONE 10(5):e0126754. doi:10.1371/journal.pone.0126754

Stickler CM, Nepstad DC, Azevedo AA, McGrath DG (2013) Defending public interests in private lands: compliance, costs and potential environmental consequences of the Brazilian
Forest Code in Mato Grosso. Philos Trans R Soc Lond B Biol Sci 368:20120160. doi:10.1098/rstb.2012.0160

Toomey M, Roberts DA, Caviglia-Harris J, Cochrane MA, Dewes CF, Harris D, Numata I, Sales MH, Sills E, Souza CM (2013) Long-term, high-spatial resolution carbon balance monitoring of the Amazonian frontier: predisturbance and postdisturbance carbon emissions and uptake. J Geophys Res Biogeosci 118:400-411. doi:10.1002/jgrg.20033 